Article

\title{
Eastern Patristics on Human's Free Will and Divine Predestination: Conceptual Continuity in the Contemporary Russian Culture
}

\author{
Olga Chistyakova ${ }^{1}$ and Denis Chistyakov ${ }^{2, *}$ \\ 1 Department of History of Philosophy, Faculty of Humanities and Social Sciences, Peoples' Friendship \\ University of Russia (RUDN University), 6 Miklukho-Maklaya Street, 117198 Moscow, Russia; \\ chistyakova-ov@rudn.ru \\ 2 Hotel Business and Tourism Institute, Peoples' Friendship University of Russia (RUDN University), \\ 6 Miklukho-Maklaya Street, 117198 Moscow, Russia \\ * Correspondence: chistyakov-di@rudn.ru
}

Citation: Chistyakova, Olga, and Denis Chistyakov. 2021. Eastern Patristics on Human's Free Will and Divine Predestination: Conceptual Continuity in the Contemporary Russian Culture. Religions 12: 900. https://doi.org/10.3390/rel12100900

Academic Editors: Michal Valčo, Jove Jim S. Aguas and Kamil Kardis

Received: 25 August 2021

Accepted: 8 October 2021

Published: 19 October 2021

Publisher's Note: MDPI stays neutral with regard to jurisdictional claims in published maps and institutional affiliations.

Copyright: (c) 2021 by the authors. Licensee MDPI, Basel, Switzerland. This article is an open access article distributed under the terms and conditions of the Creative Commons Attribution (CC BY) license (https:// creativecommons.org/licenses/by/ $4.0 /)$.

\begin{abstract}
This article deals with the most crucial philosophical and theological issue of correlation of freedom, freedom of will, and Divine predestination, which arose in shaping the Christian doctrine and remains emergent for contemporary Russian culture and society. This problem permeated all the centuries of Christianity's formation, beginning with the period of apologetics, but it reached its climax in the classical Patristics epoch during the Byzantine Trinity and Christological theological disputes between the Western and Eastern Church Fathers. In theological discussions, they formed subtle differences, characterizing the discrepancy between Eastern and Western Patristics representatives' views. We analyze the creative heritage of Greek-Byzantine (Eastern) Patristics, influencing the relationship between human freedom and Divine predestination, also conducting some comparative analysis with Western Patristics. The attention is also focused on the subtleties mostly of the Greek Church Fathers' comprehension of connections between free will and freedom of choice, which correlates with human rationality, high morality, and choice of deification as a movement towards God. Philosophical reflection of described ideas of Eastern Patristics is also carried in conjunction with Christian soteriology, that is, the doctrine of spiritual salvation and eternal life. A prominent place in the article is given to some ideas of deification, the moral perfection of personality, and the Absolute spiritual ascent. The article stands on the original teachings of prominent Saints of Eastern Christianity-Maximus the Confessor, Athanasius of Alexandria, Gregory of Nyssa, John of Damascus, and Justin Martyr as a predecessor for both the Eastern and Western Patristics. This article also examines the refraction of the ideas of Church Fathers in contemporary Russian culture and philosophical studies of Patristics and Byzantine philosophy. Adhering to the Russian academic tradition of Byzantology, we present some implementations of Greek Church Fathers' ideas, particularly on free will and Divine predestination, in the works of gifted Russian Byzantologist scholars. We try to attract the reader's attention to the valuable Byzantine heritage in order to continue the tradition of studying the Church Father's legacy in our country.
\end{abstract}

Keywords: philosophy of religion; Christian theology; Greek-Byzantine Patristics; freedom and predestination of God; deification; Russian culture

\section{Introduction}

The everlasting contribution of the Greek-Byzantine Patristics to the history of culture and religion might be best unveiled by the philosophical consideration of the most vital doctrinal issue on the interrelationship among freedom, freedom of will, and the Divine predestination. The Church Fathers elaborated these ideas throughout Late Antiquity and the Early Middle Ages.

The Hellenistic period was absorbing relevant philosophical concepts and teachings of Ancient Greece and Rome, trying to institute the state, religion, and science at times 
of the emerging Christian culture (Chadwick 1993). There also appeared an urgent and ongoing necessity to define the human being's quintessence and to comprehend the extent of personal cognition of life and its meanings, interrelation of man and God, and some epistemological ways of coming to know about the Absolute. The mystical and gnostical teachings and philosophical schools in the Early Medieval epoch attempted to address those issues. However, amidst the wide variety of mystical, religious, and philosophical gnosis, a new monotheistic creed rapidly gained adherents.

Christian contemplation (Weltanschauung) of the Universe and evolving theology were gradually morphing into the spiritual basis of the developing Medieval society. Nevertheless, despite their common theoretical source, Christianity in the Byzantine Empire and Christianity in the Western provinces of the former Roman Empire were molded in their specific ways, with some dogmatic and cultural peculiarities. All philosophical and religious justifications within West European and Byzantine philosophy were unique as they differed essentially both in content and style (Whittow 1996). Besides, the religious dogmas of Western and Eastern Christianity elaborated by the Latin and Greek Patristics had their particular meanings and characters. Some dogmatic variances and philosophical contradictions between early Western and Eastern Christianity laid the cornerstone for the forthcoming Great Schism.

The 4th century witnessed the acme in Patristics' casting with the principal Christian orthodox dogmas being forged and the essential discrepancies between the conceptions and notions of West European and Byzantine Medieval philosophy-both immanently connected with Christianity - being defined. Subtle doctrinal differences of Western and Eastern Christianity were most prominent in the Church Fathers' works substantiating philosophical and anthropological ideas, epistemological categories, and moral values. Western Christianity, tightly corresponding to the Roman tradition, was primarily characterized by rationalism and hieratic practices and less inclined to theological theorizing than its Eastern branch ${ }^{1}$. However, the relationship between individual freedom gifted by God and its fulfillment through a sophisticated personal way of ascending to God was a key issue among those discussed by Western and Eastern Church Fathers.

Thus, as an entire religious and cultural phenomenon, Patristics sculpted the Christian creed, also designed its religious anthropology. Academicians from Slovakia Ján Zozulăk and Michal Valčo emphasize the gist of Byzantine anthropology: " $<\ldots>$ Byzantine anthropology implies a relationship of the human being to God and of the human being to the human being. In this perspective, Byzantine philosophical thinking also analyzes the goal of the life of the human being" (Zozulăk and Valčo 2018, p. 1039). A significant theological and anthropological problem there was the dependency of the human's freedom, free will, and free choice from the Divine predestination. Underlining the considerable meaningfulness of Patristics, the German philosopher Georg Hegel wrote: "All the questions concerning the God's nature, the Human's will, the relation to God, Who is the Object, the origin of evil, etc., were examined by Church Fathers, who accepted and introduced the final answers to those eternal questions to the Christian dogmatical system. The nature of spirit, the order of salvation, i.e., the scales of a person's spiritualization, his upbringing, the progressive advance of spirit, $\langle\ldots\rangle$ all these transformations were comprehended accordingly to the spirit's manifestations, considering the spirit in its freedom and in its depth" (Hegel 1935).

In the submitted article, we consider merely Eastern Church Fathers' conceptual ideas, manifesting the specificity of their thought and sights on the human beings' nature, their freedom, and their relation to God. We also underline the realization of Church Fathers teachings in contemporary Russian thought.

\section{The Conception of Free Will and Predestination in the Soteriological Context}

In the Greek-Byzantine Patristics, with its dominating theocentric thinking, such essential philosophical issues as human freedom and predestination, spiritual interrelations of individual and God, possibilities of knowing God determined the Christian soteriological doctrine. According to Alister E. McGrath, "The Greek word soteria has a number of 
meanings going beyond the conventional translation "salvation", including "liberation" and "healing" - as in being released from danger or captivity, or being delivered from some form of fatal illness" (McGrath 2017, p. 83). In Christianity, this dogma designed possibilities of salvation for each person and uncovered the mysteries of the eternal spiritual life in the Divine world after an individual's death. Thus, the category of salvation had become a basic one in the Christian doctrine. However, its true meaning included a dualistic explanation. Salvation was interpreted as the most significant goal of each human being's moral and religious inspirations, and as the Divine grace given by the God-Creator to those who share the idea of deification, making their religious path to God by the ascension to the spiritual unity with God.

The idea of salvation and its substantiation directly opposed the concept of the Fall from Grace as the ideals of salvation set out the righteous path of self-perfection, moral and spiritual purification of a human being, ways of knowing God's revelations, and individual self-cognition that would be ended in the mystical unity of a person with Deity. The idea of a man rising to God was reconciled with the possible revival of God's image and likeness, lost through the original sin, and attainment of eternal life. The dogma of the God-man Jesus influenced the soteriological teaching profoundly because the Incarnation of God the Son was justified by the atonement of humankind, drowning in sin. Christ's Incarnation made it possible for people to achieve salvation for both the conciliar human nature and each person. The ecclesial mind and each person's Christian spirituality were fundamentally essential to cherish the desire to reach the miracle of eternal life. These ideas were considered anthropologically and eschatologically. In this context, Zozulăk and Valčo point out the following: "Byzantine anthropology emphasizes that the human being is temporary in this world; hence it leads him to be rid of every clinging to perishable things. At the same time, it encourages him to experience God's truth eschatologically and to desire to live for eternity already now. In this view, it is not the beginning, but the end determined for the human being by God that clarifies the goal of the life of the human being. It is not only a historical perspective, but especially an eschatological one, as Byzantine philosophers claim" (Zozulăk and Valčo 2018, p. 1039).

The reasoning of the ideas of salvation and atonement in Eastern Patristics was explicitly coordinated with the Church Fathers' explanation of God's original purpose, which was the deification of all the terrestrial world with humanity's fulfillment the free council of an individual and the God-Creator. To reveal the ways of achieving the desired salvation and the spiritual unity of the human being with God, the God-man dogma was introduced into the Christian orthodoxy. According to that doctrine, Jesus Christ, incarnated in the man's body, would help an individual return the lost God-likeness on the path of personal moral ascension to the Absolute. Athanasius of Alexandria communicated in his work: "We had become an inspiration for God's incarnation. He showed so much benevolence for our salvation that He embodied Human's flesh and people witnessed the Christ Epiphany" (Athanasius of Alexandria 1994, p. 196).

In Christianity, salvation is the mysterious union between the human and Divine nature to pursue eternal life. The path of salvation within the Eastern Patristics convention was regarded as a specific synthesis of humankind as a whole and the individual nature of every person. Salvation entirely overcomes a person's alienation and lack of freedom, a human's captivity to sin in the created world. Thus, the notion of salvation in Church Fathers' works bears the apophatic meaning insofar as the ideals of salvation seem to be denying death, the corruptible nature of the human being, the very possibility of $\sin$ (Dura and Chiriluță 2015, pp. 40-41), as well as imperfection and unrighteousness existing in the material world.

According to the Eastern Church Fathers, the omnipotent God purposely takes responsibility for human peccancy to cross the abyss between the Divine and mundane worlds. Thereby, God-man's phenomenon was perceived as contradictory, though any antinomy was a priori excluded from understanding the God-man as a Person. Gregory the Theologian emphasized this subtle point by noting that the correlation between human freedom 
and free will was solved precisely in the God-man dogma. He remarkably affirmed that Jesus Christ, with His Incarnation, possessed a miracle-working power to recover the coherent nature of each man in its coordination of body and soul and the human inherence to the conciliar sacred essence given by Christian spirituality. The latter includes freedom in general understanding as well as an individual's free will. Gregory the Theologian wrote in this context: "When Christ beheld that a soul-destroying sin had exterminated everything heavenly incorporated in a human body $\langle\ldots\rangle$, at that time, for returning His own Divine inheritance He didn't send different sort of helpers to recover from sickness but $\langle\ldots\rangle$ being Immortal became Mortal and appeared through Virgin Mary, the Mother of God, in order to save Man in his integrity" (Gregory of Nazianzus 1994, pp. 35-36).

The Church Fathers justified the necessity of the God-man's advent and His death on the cross both ontologically and anthropologically. Having lost dignity of their position as the acme of God's creation, people per se no longer possess the possibility of deification and unity with God. They need the help and spiritual guidance of Jesus Christ in these endeavors. Besides, the phenomenon of the God-man was burdened with the potent psychological meaning. According to the Russian scholar Sergei Averintsev, the death and resurrection of Jesus Christ should be characterized as " $<\ldots$ the event appealing to the most striking feelings of a human and making the most pressing demands towards each human being" (Averintsev 1974, p. 184), as the Lord was sacrificed for the humanity's atonement to save all the people from sinfulness ${ }^{2}$.

At the dawn of Christianity, the apologist Justin Martyr, one of the first Church Fathers, outlined significant points of a new monotheistic religion's soteriological doctrine. He noted: "When the measure of our impiety had been overfilled $\langle\ldots\rangle$ God himself on His infinite human-loving $\langle\ldots\rangle$ bore our sins. God-Father sent His Son to suffer for our redemption, the Most Holy for the wicked people, the Innocent for the guilty, the most Righteous for the sinful, the Incorruptible for the corruptible, the Immortal for the mortal" (Justin Martyr 1995, pp. 380-81). However, the principle of antinomianism, penetrating Christian anthropology, was not eliminated by the ideas of atonement and salvation. Having lost his own a priori ontological equality with the Creator-or God's likeness-a human being himself cannot return this transcendental position as the essential feature of humanity. The human beings can bring it back only as the result of God's goodness, as His gracious gift that let people rejoice and reconcile in Divinity and religious spirituality. The Church Fathers' doctrine of the Divine essence and the Divine grace developed from the abovementioned ideas (Melford 1966).

Thus, the Eastern Holy Fathers explained the interrelation between the Divine invisible and the visible worlds. The righteous path in the mundane world leads the Christians to implement the primary goal, i.e., the salvation they strived for. From this perspective, salvation ideals encouraged theologians to create a new human design - the so-called new creature within Christian monotheism. Salvation a priori signified self-perfection and selfcognition in the process of knowing God, elevating every human being over the sensible world (Kirabaev and Chistyakova 2020, p. 2). Such kind of life is aligned to the path of deification, i.e., of individual perception of the best Divine qualities. In this context, the God-man's death on the cross is manifested in the Eastern Church Fathers' works primarily as an essential means of achieving the individually cherished objective of deification and unity with God.

The Patristic reasoning of the atonement and salvation doctrines represents the part of Christian soteriology that expresses its implementation as a righteous act of the Lord. However, the aims of deification are not wholly achieved at this stage yet. Therefore, Eastern Church Fathers developed the ways and means that everyone should undertake personally to attain spiritual unity with the Creator.

The famous Gregory of Nyssa's book On the Making of Man, brings out the profound philosophical idea of conciliar holistic human nature as the principle of universal salvation. According to St. Gregory, "For the image is not in a part of our nature, nor in the grace in any one of the things found in that nature, but this power extends equally to all the race < 
$\ldots>$ the man that was manifested at the first creation of the world, and he that shall be after the consummation of all, are alike: they equally bear in themselves the Divine image. For this reason, the whole race was spoken of as one man $<\ldots>$ Our whole nature, then, extending from the first to the last, is, so to say, one image of Him Who is" (Saint Gregory of Nyssa 2016, chap. 16). Thus, it is God's image that a priori tethers every individual to virtue, the righteous sacred things, absolute values and unites the diverse human nature in a pretty perfect council, or shared spiritual substance inherent in all the human beings.

When explaining the contradictory interrelation between the Divine and earthly worlds, the theologian primarily tried to theoretically rationalize the interactions between the spiritual and the carnal, the eternal and the perishable, the man's nature dwelt with sin and vice, and its opposition, free from evil and sinfulness. "There is a great difference between that which is conceived in the archetype, and a thing which has been made in its image" (Saint Gregory of Nyssa 2016).

Saint Gregory's argumentation holds the philosophical and anthropological features concerning the issues as mentioned above. He scrutinizes the philosophical categories of "general" and "singular", using them for theological analysis. According to the Church Father, the created man is granted the traits of conciliar spiritual nature, and that continues to exist in every individual, being a specific ground for the divine, mystical unity of God and man. The conciliar essence of humankind per se may reinstate itself through the initially inherent divine archetype. Moreover, the human entity's total unity defines personal qualities and distinguishes an individuum and a person essentially. Therefore, man's creation in the image and after God's likeness implies the conciliar spiritual nature embracing the earthly and Divine worlds, rather than any feature of an individual.

As soon as the original sin conquered man's entity, the consistent conciliar human nature obtained its internal dichotomy of individuality versus the integrity of its essence. Individuality is a particular bearer of the wholeness and a component of the holistic Universe. Individuality manifests itself in sensibility, appetency, passions, affections and affectations, sinful thoughts, and evil intentions. However, the conciliar essence of the perfect nature, a priori granted by God, has been held and manifested in absolute kindness, benignity, beauty, reason, wisdom, virtue, love to other people, and the Maker.

According to Gregory's opinion, man's inconsistency reveals the gist of the human being and humankind as a coherent integrity. St. Gregory writes: "While two natures-the Divine and incorporeal nature $\langle\ldots\rangle$-are separated from each other as extremes, human nature is the mean between them: for in the compound nature of man we may behold a part of each of the natures $\langle\ldots\rangle$ - of the Divine, the rational and intelligent element, which doesn't admit the distinction of male and female; of the irrational, our bodily form and structure, divided into male and female: for each of these elements is certainly to be found in all that partakes of human life" (Saint Gregory of Nyssa 2016). So, to be saved, a person must recover humanity's conciliar nature, which was once God-granted to the First Man.

There is a fundamental difference between two patristic traditions-Eastern and Western-drawn from those mentioned above philosophical and anthropological explanations of mutual relations between God and man. Representatives of the Eastern traditionAthanasius of Alexandria, Gregory of Nazianzus, Gregory of Nyssa, Basil of Caesarea, John Chrysostom, and others-assumed the crucial take of conciliar essence of man, proposing the spiritual unity of people belonging to the Church of Christ. On the contrary, for the Western Patristics, specifically for Augustine of Hippo, it was typical to scrutinize the individual human nature (Evans 1993), revealing its self to the Lord on the way of self-perfecting and self-becoming.

\section{Freedom, Freedom of Will, and Predestination of God as Anthropological Ideas of Eastern Church Fathers}

Going back to the Early Christian period, we should mention that the centuries-old discussions of Divine predestination, God's grace, and free will drew from the problem of interrelation of God's mercy and activity of man for the achievement of salvation that 
had been under the detailed consideration of both Eastern and Western Church Fathers. In Eastern Christianity, the categories of free will and freedom obtained different conceptual significance. Eastern Church Fathers conceived of free will as the free determination of an individual searching for his direction in life. It may be the straight righteous path to Lord, or another one denying the absolute morality and tending to dwell with sin and evil. The notion of freedom manifests the acme in spiritual self-perfecting and self-knowing in the religious sphere. Thus, the theorizing of the Church Fathers concerning the concept of free will appears to be a significant part of the consideration of freedom per se.

Justification of the category of freedom was incorporated into explaining the antinomic relationship between God's absolute freedom determined by His triune essence and relative freedom of choice of an individual as it is a priori affected by the consequences of the original sin. There was subtle reasoning behind the dialectical correlation of the Divine predestination and personal freedom of will and freedom of choice ${ }^{3}$. The central part of the deification process, lofted every man and paved the way to their salvation, is occupied by God's grace and His help, followed by a person's own moral and spiritual efforts, the strength of individual will, and the internal desire for a righteous life.

Sergei Bulgakov, the famous representative of the Russian religious philosophy of the late 19th-early 20th centuries (it is known as God-seeking), interpreted the Greek Church Fathers' ideas of salvation as the personal feat of man. He claimed that salvation was a permanent process of deification characterized by the conciliar nature (we would pick this profound point from the Gregory of Nyssa's reservoir of ideas), and man is a pillar of this heavenly guidance mostly inside his soul rather than outside him. Sergei Bulgakov marked in this context: " $<\ldots>$ salvation is [the authors] $<\ldots>$ the internal blessed activity inside a man, which is being performed only by using the human freedom not excepting an individual himself" (Bulgakov 1991, p. 236).

Yet no matter how hard the Greek-Byzantine thinkers thoroughly tried to resolve the challenge of the interrelation between heavenly and earthly worlds, the internal antinomianism of Christian doctrine, which combines opposing positions-the gracious omnipotence of God and the individual responsibility for decisions and actions-persisted. The predestination of human destiny is to be implemented under the effect of Divine grace, and it means the achievement of salvation and eschatological eternity by every righteous person. The predestination is described with the absolute character with the supernatural predetermination of everything human and the relative one, that acknowledges the vital meaning of an individual in his endeavors to reach the spiritual unity with God, thus achieving spiritual immortality.

The advanced consequences of these ideas are found in the works of St. John of Damascus, who contended that a person's fate and behavior depended on free will and freedom of an individual choice rather than on Divine providence. He incorporated the notion of foresight in this discourse and noticed that the Creator could foresee everything but not at all things were under His predestination. Being omnipotent, God is to foresee all the human's acts and behavior, but having granted freedom to every individual, $\mathrm{He}$ does not predestinate them (John of Damascus 1992, pp. 115-18). It is worth noting that there existed a variety of views on this issue within the Western Patristics. On the contrary, in Byzantium, the John of Damascus's thesis was the fundamental one for all the representatives of the Eastern Patristics over the ages of this civilization's history.

Despite St. John's stress on a person's activity, both in Western and Eastern Patristics in the God - man dichotomy under the consideration the part of Absolute was overemphasized with the other one-individual—humbled. Saint Irenaeus (Lugdunensis—Latin), one of the first Church Fathers who laid the foundation for further development of the patristic tradition, clarified the mentioned theoretical pillar using an orthodox statement that only God was to be seen as the Maker of all the living. However, even being the top of Divine creation, the man was not able to possess such kinds of functions. Thus, to achieve salvation and spiritual immortality, to quote the Russian academician Sergei Averintsev, " $<\ldots>$ a man is called to find out void in themselves and with an act of humility to manifest 
this nothingness to God" (Averintsev 1967, p. 449). A person striving for God should rely on the individual righteousness and the Heavenly grace as an act of the Creator's free will. The duality of the human and God's performance approaches a man to the achievement of cherished deification. The idea of the necessary unity of the Divine grace and constant vigorous activity of a person penetrates almost all Greek theologians' works and characterizes Eastern Patristics as a whole.

The analogous thought was already inherent to the works of early Christian Church Fathers. Origen of Alexandria in his treatise "On First Principles", underlined that nor human freedom without longing to know God, as far as it may be immanent to man, nor knowledge of Divinity in itself, did not induce an individuum to the self-performing and self-cognition lacking the personal striving to reach an Absolute (Origen 2007). Later, Gregory of Nyssa contended that man, even having lost freedom, possesses volition that, according to God's grace, is to give him a possibility to restart his way consciously, sweeping the mistakes fallings away and redeeming sins by the new virtuous path (Saint Gregory of Nyssa 2016). Thus, a reasonable combination of a person's will with God's predestination and grace is some kind of the golden mean, which is to encourage every man to recover the lost likeness at any period of his life, but accordingly to the activity of a man.

Saint Gregory teaches that freedom manifests itself provided that human love exceeds the boundaries of the own psychophysical entity, forgets the individual's self, and is being conveyed to another human in its all-encompassing emanation. A person is delivering oneself from the natural determination, having a possibility to define themselves in any way, and a capability to overcome the imposed limitations to achieve the level where the individual traits are transformed into the absolute conciliar sense of love. It can be attained only in the state of a total conflux of the man with God. Every human being should consciously choose his way of obtaining freedom and rising to God. Only people with a rational mind may purposely guide their nature (St. Gregory of Nyssa) and command their passions and desires, simultaneously protecting themselves from evil and sin present in everyday life. In concert with St. Gregory's ideas, John of Damascus wrote: “By Divine necessity, freedom of decision is integrated with reason because either a man is not a rational creature or being rational, he is the independent master of his actions. Hence, irrational creatures are not free in essence, for they are rather guided by nature than themselves lead it" (John of Damascus 1992, p. 109).

The Eastern Patristics brought God closer to the human being. Having created the man and endowing him with free will, God acquired a kind of weakness before him. Freedom has its source in the mercy and omnipotence of the Creator, and therefore God cannot exercise compulsion or constraint in relation to the individual's will. This also counts to God's all-embracive love for the man He created. Vladimir Losskiy commented as follows: "Divine will always be submitting itself to wanderings, deviations, even revolts of human will, in order to bring it to consent" (Losskiy 1991, p. 244).

The correlation between Divine predestination and free will is fundamentally antinomic, just as the understanding of man from the Christian Orthodox standpoint. "The Byzantine Orthodox anthropology turned out to be antinomic, open in its essence toward the Divine transcendent direction as well as toward the mundane, human one. Such unity of opposites within the framework of the Byzantine cultural system exalted the spiritual (i.e., the Divine) principle in Man and, at the same time, spiritualized the carnal origin" (Chistyakova 2019, p. 152). As an object of Divine grace, an individual is to be sin-struck, being at the same time endowed with completely conscious freedom, rationality, and the ability to make choices at any time of his life. This contradiction was partly removed through the synthesis in the notion of providence. However, the problem has not been resolved to its full extent in the Patristics' texts, and the issue persists in Christian theology and Humanities, influencing contemporary cultures, particularly the Russian one. 


\section{Legacy of Church Fathers' Ideas on Free Will and Divine Predestination in the Contemporary Russian Culture}

In Russia, as in Western countries, the tendencies toward secularity in public life, social, and cultural spheres have become apparent in recent decades. However, there have been opposite trends in the country's secularization processes. The new social institutions and groups of people do not exclude the existence or even actualization of theology, religious diversity, and the aspiration of a modern person to religious self-identification along with ethnic, civil, and political identity. This has intensified attention to Russia's religious past. The ideas that emerge in history can be used to understand better and objectively explain the present.

Russian culture has existed for centuries in harmony ${ }^{4}$ with the canonical and philosophical provisions of the Eastern Christian Church. This relationship persists even today among people who profess Orthodox Christianity and belong to the Russian Orthodox Church. It was noted above that, along with the discussion of dogmatic questions, a very significant problem for Eastern Patristics was the development of an anthropological religious concept within the relationship between human freedom and Divine predestination. At present, this question remains central in Orthodox Christian theology and the philosophy of religion, despite secularization processes in Russian society. It seems that secularization $^{5}$ nowadays even increase the importance of considering the problem of man and his freedom, which has arisen in Christian history, for making sense of current culture.

A holistic consideration of the man requires an analysis of his existence in the historical epoch, the depth of temporal-spatial space, which somehow affects each individual's personal history in modernity. Furthermore, the individual "highlights" by his activity the state of society and those conditions of cultural existence in which his life proceeds. Therefore, modern-day Russia, tightly linked to the historical past of Greek-Byzantine Christianity, in its cultural life is based in one way or another on the ideas of the Church Fathers, in particular, on their understanding of man in relation to God, human free will, and predestination by Divine providence, the possibilities of knowing the Creator. Of course, these issues are primarily inherent in philosophical, cultural, or theological discourse. However, even though the topic of the Church Fathers' heritage and their influence on modern culture is not widely discussed in Russian humanities science, the profound theological and philosophical problems of early and classical Patristics are reflected in the relevant Russian literature.

In present-day Russian social science and Humanities, there is a tradition of considering Eastern Christianity and Patristics, laid down by the researchers of Byzantium S. Averintsev, V. Bychkov, G. Kurbatov, S. Horuzhiy, H. Lipshits, Z. Udaltsova, and by philosophers-medievalists A. Gurevich, A. Kazhdan, V. Sokolov, A. Chanishev, and oth$\mathrm{ers}^{6}$. They share an attitude that Christian anthropology in Byzantine culture is identified as the central tradition of historical-philosophical and cultural development of Medieval Byzantium. Here are basic ideas of some of these authors, which are essential for modern academia comprehension of Eastern Patristics and the most important questions discussed by the Church Fathers.

Academic S. Averintsev wrote about Byzantine spiritual culture as remarkable integrity, provided by the unity of two opposite types of cultures and anthropological teachings-Middle Eastern and Ancient Greek, connected in the integrity by the cult of spirituality (Averintsev 2004). Notable Russian researcher of Byzantine aesthetics V. Bychkov also emphasized the synergy of the two named traditions within Byzantine philosophy and religious culture. He argues that these traditions knotted into a single whole of two different ways of achieving a personal spiritual perfection on the way to God, that is the Greek cult of knowledge and wisdom, of self-discovery for approaching the Absolute, and the Hebrew practical way of saving man from death and decay (Bychkov 1981). These two directions within the integral Byzantine culture laid the ideological foundations for the further development of Christian anthropology and epistemology, relevant even today. 
We should also note some ideas expressed by Z. Udaltsova, a well-established investigator of Byzantine history and culture. She proceeds from understanding Byzantine culture as a relatively self-developing system, which absorbed the most paramount components of previous philosophical and religious teachings. She emphasizes that the anthropological problematics was the basis for all the Trinity and Christological disputes that influenced Byzantine culture in the 4th and 5th centuries (Udaltsova 1988, p. 43).

In contemporary Russian studies of religious and cultural trends within the Byzantine ecumene, a discourse is emerging and developing regarding the correlation between human freedom and its determination by the Divine will. The discussion by Russian philosophers and theologians (V. Bolotov, I. Ekonomcev, A. Men, and others) regarding the anthropology of Church Fathers of early and Medieval Christianity draws from the foremost tenets of Christianity: creationism, theocentrism, the creation of man in the image and likeness of God, the predestination of a life path, and the endowment of freedom of choice. These principles, however, do not prevent theologians from viewing man as a free, active person. Based on the individual choice, a person constructs his way of life to achieve spiritual unity with the Creator.

We believe that such ideas naturally and legitimately find reflection in current $\mathrm{Hu}$ manities and theological thought because the power of religious ideas lies mainly in the philosophical conditionality of human freedom and choice. These ideas belong to the category of eternal philosophical questions. The modern consideration of the relationship between individual freedom and Divine predestination and the role of higher grace in human life tends to follow the traditional patristic view of the problem, although there are some peculiarities. While the general idea of defining freedom is choosing between good and evil, Russian studies emphasize the immanent moral component. In the books of the authors mentioned above and many others, freedom is directly associated with personal purification and perfection, the pursuit of spiritual values (despite the total technocratization of society), and moral ideals. Freedom of choice is thus designated as freedom from sin and the material world.

This modern interpretation is largely refracted from the legacy of Russian religious philosophy of the late 19th and early 20th centuries, where God-seeking philosophers wrote out the norms of religious morality to overcome the contradiction between freedom of choice and Divine predestination. For instance, in N. Berdyaev's works, the antinomianism between the man and God, freedom, and predestination is overcome by creativity, which is the cooperation of a human and God. According to Berdyaev, freedom is man's response to the call of God. It takes a free effort of the spirit to prevent the decomposition of the self, the splitting, and disintegration of the personality into parts. Through freedom of choice, man chooses God and through creativity, revealed in spirituality, achieves unity with God. For such unity to be realized, the transformation of man through the world of culture, spiritual values, and creativity, is necessary. "Spirit is freedom, and freedom is the victory of the spirit" (Berdyaev 1995, p. 17). In the vein of Eastern Patristics, Berdyaev believed that an individual could free themselves from the dependence of being and achieve freedom only in a spirituality associated with the search for God. Freedom is the creative ability to rise above one's natural necessity and transform life according to absolute regulations and values.

The issues of freedom and choice, which were raised at the dawn of Christianity and in Russian religious philosophy in the 19th and early 20th centuries, remain crucial to Russian philosophy and cultural studies in the early 21st century. In modern society, the patristic legacy must outline one of the mechanisms of human self-determination, designating personal purpose as a creative search for the acquisition of meanings of existence. From the Church Fathers' insistence on the activity of an individual, belief in spiritual possibilities came to a crucial religious-philosophical position that has not lost its rationality today, i.e., the perfect life, personal and social, is created by people themselves based on spiritual values and moral norms. 


\section{Conclusions}

Summarizing, it is worth mentioning that the understanding of free will and free choice in their relationship with Divine predestination in the Eastern Patristics was determined by the main doctrinal postulates of Christianity - by the God-man dogma and the Old Testament thesis about the creation of man in the image and after the likeness of God. Greek Church Fathers substantiated the idea of human freedom caused by the free will, originally granted by the Creator and reasoned by the spiritual God-likeness, incorporated initially into the first man and woman essence. The meaning of the God-likeness presumed the implementation of the human being's freedom on the path of deification, religious gnosis, and salvation.

God, by His absolute freedom, stipulates the existence of human freedom in the mundane perishable world. However, Divine predestination does not prevent a person's moral purification and self-perfection and his creative self-development and spiritual ascending to God. Thus, according to Eastern Patristics, salvation can be merited by people in the process of high moral, religious life.

The Eastern Christian tradition does not reject the grace of God, but, as distinct from Western Christianity, it is a supportive power for reaching eternal life (salvation) in eschatological prospect. Therefore, the idea of God's predestination expresses both the foresight of individual destiny and recognizing a person's role in achieving freedom and God-likeness, lost because of the original sin.

Generally, in terms of free will and predestination doctrine, the Eastern and Western Patristics share theoretical ground in the human being's reasoning as an active creature who is profoundly wise in choosing a virtuous life, knowing God, and trying to achieve a spiritual unity with the Creator. Nevertheless, Eastern (Greek-Byzantine) Christianity stresses the personal self-dependence point more clearly and conspicuously than in Western religious tradition with its justification of the enormous strength of the Divine predestination.

Despite the seeming historicity of this topic, it is highly relevant in Russian culture and the Humanities, since it is related to the eternal theme of human freedom, the discussion of the role of religion in society, and the significance of the idea of God for individual human experience. There is a scholarly discussion of the ideas of the early and Nicene Church Fathers in Russian philosophical and religious studies that seems constructive for the development of both science and culture ${ }^{7}$. In our opinion, a positive feature of this discourse is that it is independent of official political, social, and economic doctrines ${ }^{8}$. Moreover, the philosophical and anthropological orientation of Eastern Patristics outlines the progressive development of the spiritual culture and mentality of society, and it substantiates the values of the human person and the possibilities of individual cognition.

The correlation of the Patristics' ideals with modernity does not mean their bare copying or imitation. The Church Fathers' heritage makes it possible to understand the applicability of this peculiar culture for modern people, the affirmation and realization of its creative powers, the implementation of their freedom, and the need to make choices contrary to societal norms. Christian anthropological values appear to us to be religious and secular, and therefore, they can unite people based on spiritual values.

Author Contributions: Conceptualization, O.C. and D.C.; methodology, O.C. and D.C.; investigation, O.C. and D.C.; writing-original draft preparation, O.C. and D.C.; writing-review and editing, O.C. and D.C.; resources, O.C. and D.C. All authors have read and agreed to the published version of the manuscript.

Funding: This paper has been supported by the RUDN University Strategic Academic Leadership Program.

Institutional Review Board Statement: Not applicable.

Informed Consent Statement: Not applicable.

Data Availability Statement: Not applicable. 
Conflicts of Interest: The authors declare no conflict of interest.

\section{Notes}

1 For more knowledge on the influence of the Greek-Byzantine Patristics on the Medieval Latin thought, please refer to Bruce (2019).

2 For more specifics on consideration of the issue of freedom of will and Divine predestination related to the forming of the Christological doctrine, please refer to Hovorun (2008).

3 For more details on dialectics of the Trinity as "exhaustively personal communion" and the man, and on the topic on Trinitarian theology of God's predestination and Human freedom, refer to King (2020).

4 Academicians often describe the relationship between Russian state and Church, Eastern Christianity, and Russian culture, taking in the historic context, using the notion of symphonia. The same term is applicable for substantiation the connections between a Byzantine emperor and a patriarch. On the latter, see Lysack (2021, p. 2).

5 We agree with C. Taylor in his definition of a secular society, which is understood as the secularization of public space, the decline of faith and religious practices, and the prevalence in culture of non-belief as a human life choice (Taylor 2007).

6 One of the recent most significant works of foreign authors on the influence of original Greek spirituality on the 18th century Russian culture, which embraced at that time the ideas of the Western Enlightenment and logic thought, is a publication of Ján Zozulăk (2021) in the journal Religions. Particularly, the author analyzes the philokalic movement in Russia as a renewal tradition drawn from the Byzantine Hesychasm, taking some ideas of Byzantine "niptic authors" into consideration (Zozulăk 2021).

7 On one of the scholar viewpoints on relationship of theology of free will and science, and on the three arguments from science on the issue of free will and the "God's will", see Aku Visala (2020).

8 For more details on some methodological and interdisciplinary reflections on the article's topic, please refer to Welker (2019).

\section{References}

Athanasius of Alexandria. 1994. The Incarnation of the Word of God. In Works of Athanasius of Alexandria in 4 vols. Moscow: The Valaam Monastery Publishing, vol. 1, pp. 191-264.

Averintsev, Sergey. 1967. Christianity. In Encyclopedia of Philosophy in 5 vols. Moscow: Sovetskaya entsiklopediya, vol. 5, pp. 447-52.

Averintsev, Sergey. 1974. Western-Eastern Genesis of the Byzantine Medieval Literary Canon. In Typology and Interrelation of the Western and Eastern Medieval Literature. Moscow: Nauka Publishing House, pp. 152-91.

Averintsev, Sergey. 2004. Greek Literature and Middle Eastern "Folklore". In Averintsev, S.S. The Image of Antiquity. Saint Petersburg: Azbuka-Klassika, pp. 40-105.

Berdyaev, Nikolai. 1995. Divine and the Human. Moscow: Republic.

Bruce, Scott G. 2019. The Lost Patriarchs Project: Recovering the Greek Fathers in the Medieval Latin Tradition. Religion Compass 2019: e12344. [CrossRef]

Bulgakov, Sergei. 1991. The Orthodox Church. Moscow: Terra.

Bychkov, Victor. 1981. Late Ancient Aesthetics. Moscow: Nauka.

Chadwick, Henry. 1993. Christian and Roman Universalism in the Fourth Century. In Christian Faith and Greek Philosophy in Late Antiquity: Essays in Tribute to George Christopher Stead. Edited by Lionel R. Wickham and Caroline P. Bammel. Leiden and New York: E. J. Brill, pp. 26-42.

Chistyakova, Olga. 2019. Religious Anthropology of Eastern (Greek-Byzantine) Patristics. European Journal of Science and Theology 15: 145-55.

Dura, Ioan, and Bogdan-Florin Chiriluță. 2015. Negation and knowledge: Apophatism as a Premise of the Mystical Experience in the Philosophy of the Vedantic Non-Dualism and Orthodox Theology. European Journal of Science and Theology 11: 33-44.

Evans, Gillian. 1993. Augustine's Paradoxes. In Christian Faith and Greek Philosophy in Late Antiquity: Essays in Tribute to George Christopher Stead. Edited by Lionel R. Wickham and Caroline P. Bammel. Leiden and New York: E. J. Brill, pp. 52-69.

Gregory of Nazianzus. 1994. Mysterious Chants. Word 8. In Works of Gregory of Nazianzus, in 2 Vols. Sergiyev Posad: Typography of Trinity Lavra of St. Sergius, vol. 2, pp. 35-37.

Hegel, Georg. 1935. Lectures on the History of Philosophy. Moscow: Sozekgiz, vol. 11.

Hovorun, Cyril. 2008. Will, Action and Freedom. In Christological Controversies in the Seventh Century. The Medieval Mediterranean. Leiden and Boston: Brill, vol. 77.

John of Damascus. 1992. An Exact Exposition of the Orthodox Faith. Rostov-on-Don: Priazovskiy kray Publishing House.

Justin Martyr. 1995. Epistle to Diognetus. In The Works of Justin Martyr. Moscow: Palomnik and Hram Publishing Houses.

King, John B., Jr. 2020. A Trinitarian Metaphisics of Predestination and Human Freedom. Theology and Science 18: 383-90. [CrossRef]

Kirabaev, Nur, and Olga Chistyakova. 2020. Knowing God in Eastern Christianity and Islamic Tradition: A Comparative Study. Religions 11: 675. [CrossRef]

Losskiy, Vladimir. 1991. The Mystical Theology of the Eastern Church. Dogmatic Theology. Moscow: SEI Publishing House.

Lysack, Maxym. 2021. Charismatic Reformer, Mystic or Father? The Reception of Symeon the New Theologian by Pentecostal/Charismatic Theologians. Religions 12: 389. [CrossRef] 
McGrath, Alisher. 2017. Theology. The Basics, 4th ed. Hoboken: Willey-Blackwell.

Melford, Elliot S. 1966. Religion: Problems of Definition and Explanation. In Anthropological Approaches to the Study of Religion. Edited by Michael Banton. London: Tavistock, pp. 85-126.

Origen. 2007. On First Principles. Sankt-Petersburg: Amfora.

Saint Gregory of Nyssa. 2016. On the Making of Man, Kindle ed. London: Aeterna Press. Available online: https://read.amazon.com/ (accessed on 21 July 2021).

Taylor, Charles. 2007. A Secular Age. Cambridge and London: The Belknap Press of Harvard University Press.

Udaltsova, Zinaida. 1988. The Byzantine Culture. Moscow: Nauka.

Visala, Aku. 2020. Theology, Free Will, and the Skeptical Challenge from the Sciences. Theology and Science 18: 391-409. [CrossRef]

Welker, Michael. 2019. Quests for Freedom: Biblical, Historical, Contemporary, 2nd ed. Eugene and Oregon: Cascade Books.

Whittow, Mark. 1996. The Making of Orthodox Byzantium. London: Macmillan, pp. 600-1025.

Zozulăk, Ján. 2021. The Influence of Greek Spirituality on Russian Culture. Religions 12: 455. [CrossRef]

Zozulăk, Ján, and Michal Valčo. 2018. Byzantine Philosophy of the Person and its Theological Implications. Bogoslovni vestnik/Theological Quarterly 78: 1037-49. 